\title{
NANOTECHNOLOGY APPLICATION ON COTTON FIBERS, YARN AND FABRIC AND ITS IMPACT ON THEIR QUALITIES AND ANTIMICROBIAL RESISTANCE
}

\author{
ARAFA, ABEER S., SUZAN H. SANAD and SHEREEN O. BAHLOOL
}

Cotton Research Institute, ARC, Giza, Egypt.

(Manuscript received 8 December 2013)

\begin{abstract}
Antimicrobial effect is derived from nanosilver particles (diameter between 1 and $100 \mathrm{~nm}$ ) which are adhered to the fibers. The cotton materials showed antimicrobial effects by killing and/or suppressing growth of a broad spectrum of microbes such as Escherichia coli, Staphylococcus aurues bacteria and Aspergillus nigera fungi depending on the surface structure of the cotton sample. The present investigation was carried out using the cotton variety Giza 86 ,to study the effect of nano-silver application on the cotton quality and antimicrobial resistance from raw to fabric.

The results indicated that nano-silver application did not affect fiber ribbon width, single fiber linear density and fiber length parameters. While, nano-silver application increased micronaire reading, both of single fiber and bundle strength, yarn mechanical properties and fabric strength. In contrast, it decreased fiber reversals number, convolution number, convolution angle, both of single fiber and bundle elongation, fabric moisture regain and fabric air permeability. The effect of the nano application was reflected positively on the zones of growth inhibition of yarn cotton followed by fabric then raw cotton. Escherichia coli gave the highest diameter of the inhibition zone. On the contrary, Staphylococcus aurues gave the lowest zone.
\end{abstract}

\section{INTRODUCTION}

Recently, an awareness of general sanitation, contact disease transmission, and personal protection has led to the development of antibacterial fibers to protect wearers against the spread of bacteria and diseases rather than to protect the quality and durability of the textiles (Chun and Gamble, 2007).

The antimicrobial effect derived from silver ions which have advantage over the conventional antibiotics, as it does not induce resistance in the microorganisms, does not lose the antimicrobial strength over time. Because of the developing resistance of bacteria against bactericides and antibodies, the irritant and toxic nature of some antimicrobial agents, biomaterial scientists have focused their research on nano-sized metal particles such as silver, titanium dioxide, and copper. Silver, in its many oxidation states (Ago, $\mathrm{Ag}+, \mathrm{Ag} 2+$, and $\mathrm{Ag} 3+$ ) has been recognized as an element with strong antimicrobial action against many bacterial strains and microorganisms (Lansdown, 2002). Nanotechnology deals with materials 1 to $100 \mathrm{~nm}$ 
in length ( 1 billion $\mathrm{nm}=1 \mathrm{~m}$ ) The role of nanotechnology application in textile industry has speeded up in the recent years. Nano-technology makes it possible to maximize the surface area of Silver particles to the highest possible. As a result, the $1 \mathrm{gm}$ concentration of silver in Nano-Silver could be able to cover 1 ton of textile. Growths of microbes in the fabrics make numerous problems such as bad smell, fabric biodegradation, and yellowish coloration, which reflect badly on the user. Thus, it's important to incorporate antimicrobial application in textile. A number of antimicrobial materials have been used for textile applications ( Gao and Cranston ,2008). Nano-silver can be applied to range of other healthcare fabrics such as dressings for scald, cavity wounds, towels ,pants and socks. it could change the properties of the applied materials .(El-Nahhal et al., 2012) stated that the physical and chemical properties of the treated cotton fibers are markedly different from those of the untreated cotton fibers.( Chaudhari et al., 2012) have observed that there is no significant change in the tensile behavior of cotton fabric treated with nano material at different concentration levels. Even at higher level of pretreatment concentration there is a minor increase in tensile property of cotton material. The antimicrobial reaction of the nano-silver particle can be explained by the following scheme using silver nitrate as the substrate and glucose as a reducing agent:<smiles></smiles>

Glucose

Gluconic Acid

Fig. 1 . Scheme of the antimicrobial reaction of the nano-silver particle interacting with glucose

As shown above in Fig .1, the silver nitrate is reduced to metallic silver by interacting with glucose (where the glucose itself is oxidized to gluconic acid). It is important to note that the present reaction does not use ammonia or ammonia water. 
The antimicrobial activity of the silver can be further explained by the following reaction in Fig. 2.

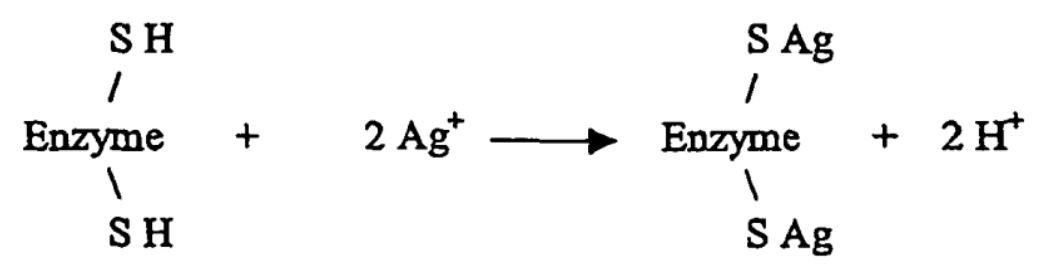

Fig. 2. Scheme of the antimicrobial activity of the nano-silver particle interacting with sulfhydryl group (-SH) of enzymes in the microorganism

Silver nitrate is one of the most powerful and widely used germicides, However, nitrates irritate the skin. Thus, it is preferable to reduce the silver nitrate to metallic silver. When the metallic silver is in contact with an oxygen metabolic enzyme of a microorganism, the silver ion interacts with the sulfhydryl group (-SH) of enzymes in the microorganism and forms an -SAg linkage with the enzyme, which effectively blocks the enzyme activity ( Jiachong and Yan 2006 )

Thus, Silver nano particles have one of the best anti-microbial characteristics covering a wide range of pathogenic micro-organisms .Silver nano particles, exhibiting very strong bactericidal activity against both gram-positive and gram-negative bacteria including multi resistant strains (Morones et al., 2005 and Panacek et al., 2006). Additional results demonstrated that Ag-NPs can inhibit fungi at 10 microgram per milliliter $(\mu \mathrm{g} / \mathrm{ml})$.Regards to this concentration, silver nano particles will lead to high antimicrobial activity compared to bulk silver metal( Lee et al. ,2003). They react with the sulfur based proteins of the cell wall in microorganisms, inhibit the metabolism and destroy the microbe (Ki et al., 2000).

\section{MATERIALS AND METHODS}

The present investigation was carried out at Cotton Research Institute, Agricultural Research Center, Giza, Egypt during 2013 season. Using the cotton variety Giza 86 because it is the most famous variety used by manufacturers and exporters. The main goal of this study was to investigate the effect of nano silver application on the cotton quality and antimicrobial resistance from raw to fabric. 


\section{CHEMICALS:}

Silver nitrate, Sodium hydroxide, Glucose, And Triton -X as a wetting agent

\section{Preparation of cotton samples}

Fibers, yarns and knitted fabrics from Egyptian cotton variety Giza 86, were scoured using $3 \% \mathrm{NaOH}$

\section{Preparation of nano-Ag cotton}

The antimicrobial cotton prepared according to (Jiachong C., 2006) as shown in the following flow chart :(1)
(a) Silver nitrate solution
(b) Reducing solution

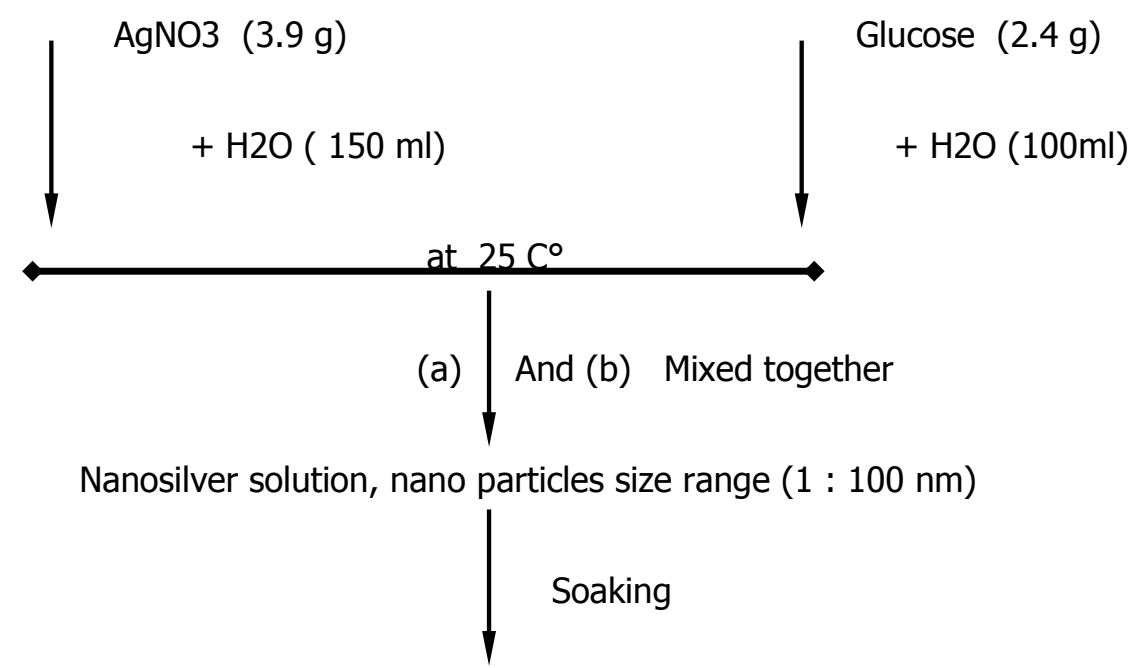

Scoured cotton samples immersed in the nano-silver solution with shaking until full absorption

Drying at $120 c^{\circ}-160 c^{\circ}$ and Washing

\section{Antimicrobial cotton (orange to brown color)}

A dry cotton sample was equilibrated in distilled water for $24 \mathrm{~h}$. the solution of Nanosilver solution prepared by dissolving $3.9 \mathrm{gm} \mathrm{AgNO3}$ in $150 \mathrm{ml}$ of distilled water then the $\mathrm{Ag}$ ions reduced to $\mathrm{Ag}$ nano particles by the Reducing solution prepared by dissolving $2.4 \mathrm{gm}$ Glucose in $100 \mathrm{ml}$ of distilled water. Thereafter, the swollen cotton sample was put in an aqueous solution of Nanosilver solution at $25^{\circ} \mathrm{C}$ for $1 \mathrm{~h}$. The 
resulting dark brown color of the grafted sample indicated the formation of $\mathrm{Ag}$ nano particles within the fibers. Finally the sample was dried at $120^{\circ} \mathrm{C}-160^{\circ} \mathrm{C}$ and rinsed with distilled water.

\section{Characterization of nano Ag-treated cotton}

Scanning electron microscope (SEM) images Fig. 3 were taken with SEM Model Philips XL 30 attached with EDX Unit -5600MD.At The Egyptian Mineral Resources Authority, Central Laboratories Sector .The Ministry of Petroleum, Egypt.
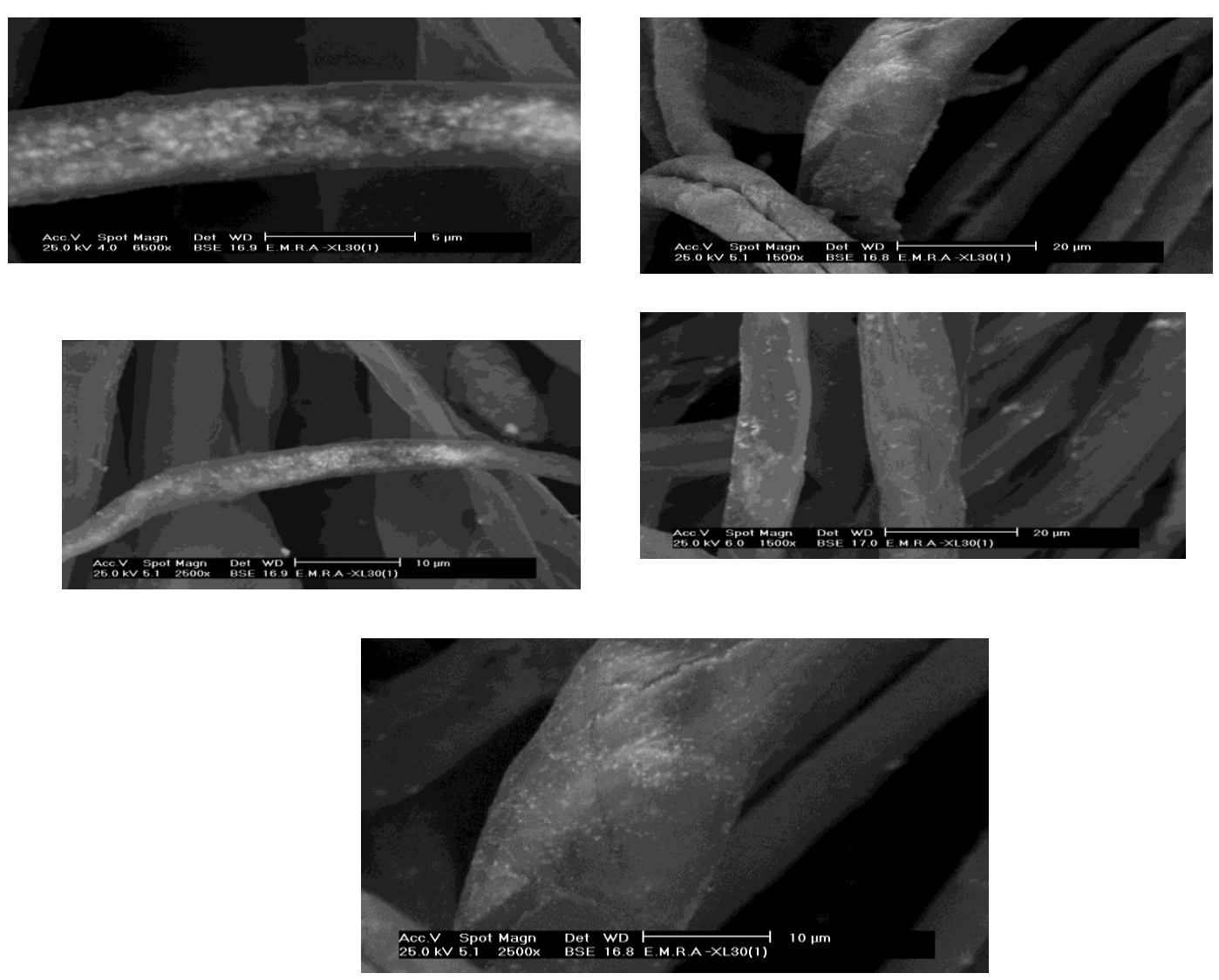

Fig.3 . SEM images of nano-particles $(1: 100 \mathrm{~nm})$ of Ag coated cotton.

\section{Fiber characters:}

micronaire reading was determined using the micronaire 275 instrument according to [ASTM D: 1448-2006].

Number of reversals per $\mathrm{mm}$, No. of Convolutions per $\mathrm{mm}$, and ribbon width in microns were tested using (G208 projection microscope according to ASTM D: 21301986). Convolution angle $=(n / 2 \times$ Average ribbon width $/ C)$ where, $C=$ Convolutions pitch length divided by the no. of convolutions ( Meredith equation 1951), Fiber strength ( $\mathrm{g} /$ tex) and elongation\%, were measured by Stelometer instrument at $1 / 8$ 
inch gauge length according to (ASTM: D1445-1982). Fiber Upper Half mean length (UHM)mm. and fiber uniformity index (UI)\% measured using fibrograph instrument according to (ASTM : D1447-1982). Single fiber measurements and force/elongation curves were performed in Textechno Herkatstein company labs Mönchengladbach, Germany.

\section{Yarn and Fabric characters:}

The cotton sample G86 was spun to 30s Ne at the twist multiplier "4.0, using the ring spinning procedure as mentioned in Table 1.

Table 1. Outline of spinning procedure

\begin{tabular}{|c|c|}
\hline Properties & Spinning procedure \\
\hline Roving count & 0.90 hank \\
\hline Roving machine & BCX 16-A Marzoli \\
\hline Roving Speed (rpm) & 600 rpm \\
\hline Spinning Machine & RST 1 Marzoli \\
\hline Spindle Speed (rpm) & 15000 \\
\hline Yarn Count (Ne) & 30 \\
\hline Twist Multiplier & 4.0 \\
\hline Ring diameter & $42 \mathrm{~mm}$ \\
\hline
\end{tabular}

Yarn tenacity (cN/Tex) and elongation at break (\%) were measured on a Statimat ME with 120 breaks per sample. Yarn evenness (CVm \%) and imperfections values were measured on Uster Tester 3 (the measurement length was $400 \mathrm{~m} /$ bobbin).

Further, yarn samples were suitably waxed and identically knitted into single jersey fabric with the same construction on a $8.89 \mathrm{~cm}$ (3.5 inch) diameter, Goge 12 with 12 needles per $\mathrm{cm}$ by DM commercial knitting machine. This was followed by Cairo Secondary School for spinning and weaving.

The knitted fabrics were evaluated for bursting strength with a diaphragm type bursting tester according to the standard method. Air permeability was determined by Prolific Air Permeability tester according to the standard procedure (ASTM D 737-04) and the results were expressed in terms of $\mathrm{m} 3 / \mathrm{m} 2 / \mathrm{min}$.

Measurements of moisture regain of the samples were performed according to the standard ASTM (D. 2495-87). Moisture regain of the samples was then determined according to the following equation: 
Where, W1: Weight of the sample (g.) after saturation in standard humidity atmosphere. And W2: Constant weight of dry sample (g.).

\section{Antimicrobial test:}

The antibacterial activity of the fabric was tested qualitatively and quantitatively by the inhibition zone method (Qin et al., 2006).Antimicrobial tests were done at Pathology Lab., Plant Pathology Research Institute, Agriculture Research Center, Giza, Egypt. Using some harmful species of microorganisms such as: Staphylococcus aurues (Gram positive bacteria) , Escherichia coli (Gram negative bacteria) and Aspergillus niger (Cloth damaging fungi).

The statistical dealing with the data obtained in this study was performed according to the procedures outlined by (Little and Hills, 1978).

\section{RESULTS AND DISCUSSION}

It's worthy to mention two control samples raw and scoured were used to be sure that all the effects are due to the nano application only.

Data represented in Table2 showed that all the microscopic characters decreased as a result of nano application due to the bonding between $\mathrm{Ag}$ ions and the free $\mathrm{OH}$ groups of the cellulose molecules. While, the effect of nano application on ribbon width was insignificant, because it is controlled with genetic factor. It's worthy to mention that the microscopic characters are not tangible but it have a great effect on the rest of characters as explained later in Tables 3:7.

Table 2. Effect of nano application on fiber microscopic characters

\begin{tabular}{|c|c|c|c|c|c|}
\hline Microscopic characters & Raw & scoured & $\begin{array}{c}\text { Applied with } \\
\text { nano }\end{array}$ & Mean & $\begin{array}{c}\text { LSD } \\
0.05\end{array}$ \\
\hline Convolutions no./mm & 4.70 & 4.60 & 3.90 & 4.40 & 0.09 \\
\hline Reversals no/mm & 1.35 & 1.33 & 1.29 & 1.32 & 0.017 \\
\hline Ribbon width $(\mu)$ & 15.5 & 15.5 & 15.6 & 15.6 & $\mathrm{n} . \mathrm{s}$ \\
\hline Convolution angle & 13.23 & 13.40 & 12.88 & 13.17 & 0.14 \\
\hline
\end{tabular}

Results in Table (3) and Fig. 5, indicated that nano application did not affect single fiber linear density. While, nano-silver application increased single fiber tenacity 
.In contrast, single fiber elongation was decreased. This may be due to the Cross linking between $\mathrm{Ag}+$ and free $\mathrm{OH}$ group of the cellulose molecule Fig. 4. The decreasing the amount of the amorphous cellulose (Abdel-Salam1999). Beside, the convolution angle became narrowed. So, decreasing the fiber elongation and increasing the fiber strength.<smiles>OC1C(O)C(O)C(O)C1O</smiles>

cellulose fiber

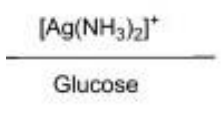

silver nanoparticle coated cotton fiber

Fig.4. Cross linking between $\mathrm{Ag}+$ and free $\mathrm{OH}$ groups of the cellulose molecule

Table 3. Effect of nano application on single fiber characters

\begin{tabular}{|c|c|c|c|c|c|}
\hline $\begin{array}{c}\text { Single fiber } \\
\text { characters }\end{array}$ & Raw & scoured & $\begin{array}{c}\text { Applied } \\
\text { with nano }\end{array}$ & Mean & LSD \\
\hline Elongation\% & $7,18 \%$ & $11.48 \%$ & $11.85 \%$ & $12.17 \%$ & 0.05 \\
\hline Tenacity(g/tex) & 45,36 & 43.04 & 50.46 & 46.75 & 0.24 \\
\hline $\begin{array}{c}\text { Linear density } \\
\text { (mtex) }\end{array}$ & 168 & 168.7 & 170.5 & 169.60 & $\mathrm{n} . \mathrm{s}$ \\
\hline
\end{tabular}

2. Forcelelongation curves

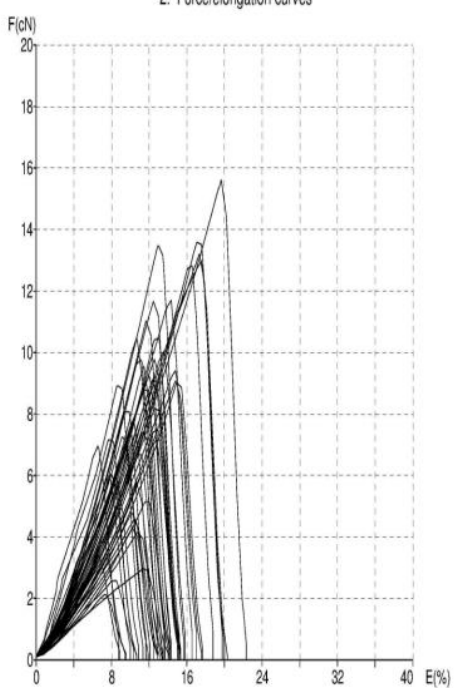

(a)

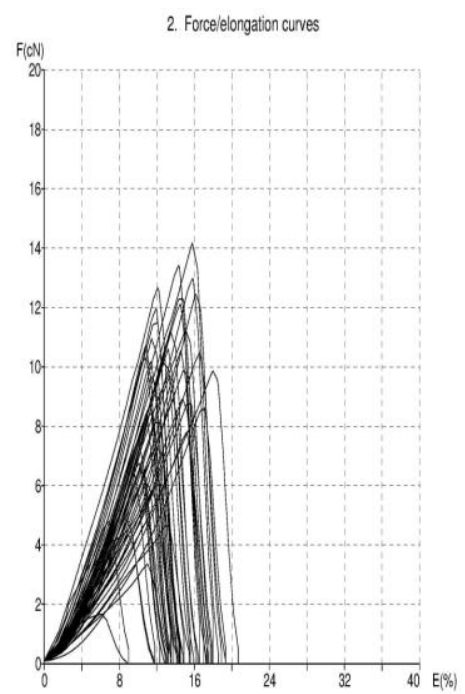

(b)

Fig.5. single fiber force elongation curve: (a) before nano application, (b) after nano application 
Table (4) evaluates the fiber physical and mechanical properties ,such as fiber length and uniformity index parameters which were not affected by nano applications. As to, micronaire reading. It increased as a result of nano application as compared to raw and scoured samples (4.64 vs. 4.42 and. 4.58), respectively .This may be ascribed to that the fiber swelled and its pores opened Fig.6. So that, the specific surface area increased but, as to this method depends on the micronaire reading, which need fixed mass of fibers, the number of fibers decreased in the fixed mass due to the swelling caused by nano applications than the raw cotton. Consequently, the micronaire reading got high ( Bahlool and Arafa, 2012)

a.

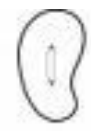

nano applications

b.

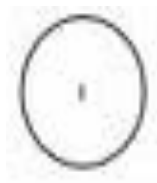

Fig.6. Model of the cross-section of the cotton fiber before nano applications (a.) and after nano applications (b.)

According to mechanical characters it is noticeable from Fig. 7 and Table (4)that nano applications increased the fiber strength and decreased the fiber elongation \% .Although nano application process needs scouring as first step which weaken the fiber Fig. 7 ,but adding nano-silver increased the fiber strength (5.6\%) than raw sample and $(7.5 \%)$ than scoured sample.

Table 4. Effect of nano application on fiber physical and mechanical characters

\begin{tabular}{|c|c|c|c|c|c|}
\hline $\begin{array}{c}\text { Fiber physical } \\
\text { characters }\end{array}$ & Raw & scoured & $\begin{array}{c}\text { Applied with } \\
\text { nano }\end{array}$ & Mean & $\begin{array}{l}\text { LSD } \\
0.05 \\
\end{array}$ \\
\hline $\begin{array}{l}\text { Upper half mean } \\
(\mathrm{mm})\end{array}$ & 33.5 & 33.2 & 33.2 & 33.3 & n.s \\
\hline UI\% & 86.4 & 85.6 & 85.3 & 85.77 & n.s \\
\hline Micronaire value & 4.42 & 4.58 & 4.64 & 4.55 & 0.08 \\
\hline $\begin{array}{c}\text { *Fiber strength } \\
(\mathrm{g} / \text { tex })\end{array}$ & 33.94 & 33.37 & 35.86 & 34.39 & 0.48 \\
\hline Fiber elongation $\%$ & 6.93 & 7.14 & 6.51 & 6.86 & 0.14 \\
\hline
\end{tabular}




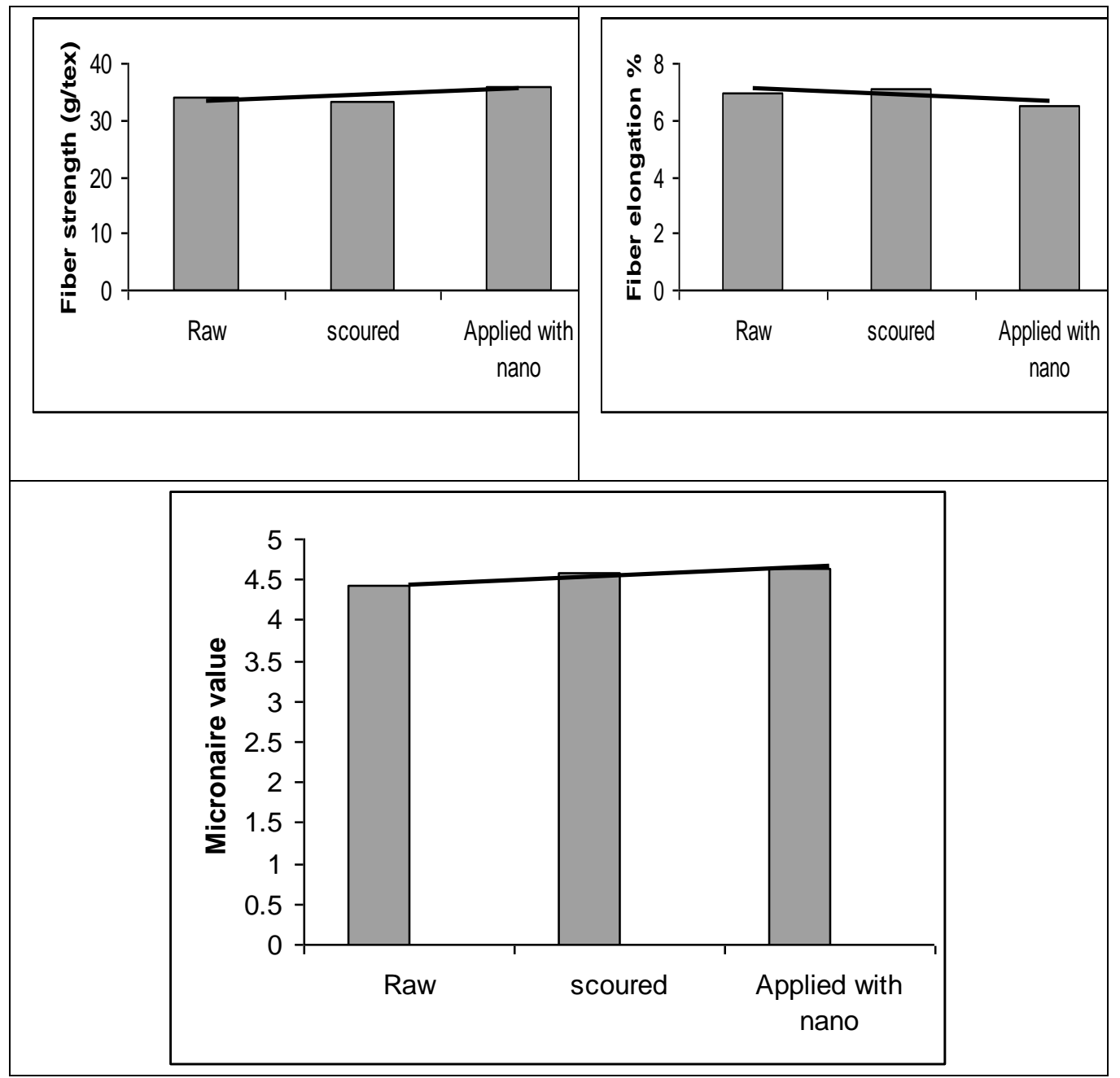

Fig. 7 Effect of nano application on fiber physical and mechanical characters

It's obvious from Table (5) and Fig. 8 that nano application increased the yarn strength this is related to the increasing in fiber strength values. The increment of yarn strength usually accompanied with similar increment in yarn elongation. Neps, thick and thin places varied from treatment to another, these differences maybe due to the nature of the sample regardless of its treatment. These results are in agreement with (Condon et al., 2008) 
Table 5. Effect of nano application on yarn characters

\begin{tabular}{|c|c|c|c|c|c|}
\hline Yarn characters & Raw & scoured & $\begin{array}{c}\text { Applied with } \\
\text { nano }\end{array}$ & Mean & $\begin{array}{c}\text { LSD } \\
0.05\end{array}$ \\
\hline $\begin{array}{c}\text { Yarn strength } \\
\text { cN/Tex }\end{array}$ & 20.65 & 20.35 & 23.31 & 21.44 & 0.65 \\
\hline Yarn elongation \% & 5.06 & 5.21 & 6.08 & 5.45 & 0.12 \\
\hline No. of neps & 7.00 & 6.00 & 10.00 & 8.00 & 0.23 \\
\hline thick places & 22.00 & 20.00 & 31.00 & 24.00 & 0.28 \\
\hline thin places & 5.00 & 4.00 & 6.00 & 5.00 & 0.20 \\
\hline CV \% & 16.23 & 16.05 & 17.26 & 16.51 & 0.34 \\
\hline
\end{tabular}
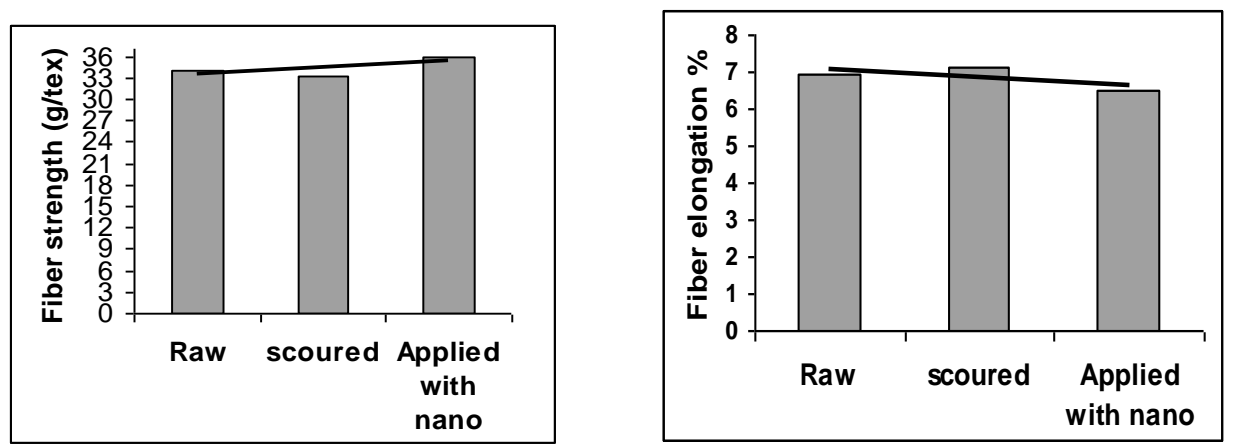

Fig. 8 Effect of nano application on yarn mechanical characters

As expected the fabric characters such as strength which described by bursting test increased as a result of nano application because of the positive effect of nano silver on fiber and yarn strength which maybe due to increasing cohesion forces between the fibers. In contrast, moisture regain $\%$ and Air permeability character decreased. These results are in line with those obtained by (El-Nahhal et al., 2012).On the other hand, ( Chaudhari et al., 2012 ) found that no significant change in the tensile behavior of cotton fabric treated with nano material. 
Table 6. Effect of nano application on knitted fabrics characters

\begin{tabular}{|c|c|c|c|c|c|}
\hline fabric characters & Raw & scoured & $\begin{array}{c}\text { Applied with } \\
\text { nano }\end{array}$ & Mean & $\begin{array}{c}\text { LSD } \\
0.05\end{array}$ \\
\hline $\begin{array}{c}\text { Bursting strength } \\
\text { kglcm2 }\end{array}$ & 11.54 & 11.27 & 16.16 & 12.50 & 0.65 \\
\hline Moisture regain \% & 6.61 & 6.06 & 4.77 & 5.68 & 0.17 \\
\hline $\begin{array}{c}\text { Air permeability } \\
\mathrm{m} 3 / \mathrm{m} 2 / \mathrm{min}\end{array}$ & 124.02 & 98.91 & 67.79 & 96.91 & 3.02 \\
\hline
\end{tabular}

The effect of Ag nanoparticles in treated cotton samples ( fibers, yarn and fabric) on antimicrobial activity was studied and results were summarized in Table (7) , Fig. , 9and 10: The zone of inhibition (diameter) was recorded in each case. Fig. 9. The observed inhibiting action of nano Ag-loaded on cotton material is due to the release of $\mathrm{Ag}+$ ions from the $\mathrm{Ag}$-nano particles present in the cotton sample. These $\mathrm{Ag}+$ ions come in contact with bacterial cells and kill them. The effect of the nano application was reflected positively on the zones of growth inhibition of yarn cotton followed by fabric then raw cotton, respectively Fig. 8 . This may ascribed to the regular shape and the low surface area of the yarn cotton comparing to the raw cotton, which is fluffy and fuzzy. Also, it could be recorded from Table (5), and Fig. 9 and 10 that Escherichia coli microorganism gave the highest diameter of the inhibition zone. On the contrary, Staphylococcus aurues gave the lowest zones. These results are in agreement with (Mastsumure et al., 2003) who proposed that Ag+ ions, released from $\mathrm{Ag}$ nanoparticles can interact with phosphorous moieties in DNA resulting in inactivation of DNA replication, or can react with sulfur-containing proteins to inhibit enzyme functions.

Table 7. Effect of nano application on zones of growth inhibition (cm) of cotton fiber , yarn and fabric

\begin{tabular}{|c|c|c|c|c|}
\hline \multicolumn{5}{|c|}{ Samples treated with nano } \\
\hline $\begin{array}{c}\text { Cotton sample } \\
\text { Microorganism }\end{array}$ & fiber & yarn & fabric & $\mathrm{M}$ \\
\hline Staphylococcus aurues & 2.50 & 3.00 & 2.75 & 2.75 \\
\hline Escherichia coli & 3.11 & 4.30 & 3.51 & 3.64 \\
\hline Aspergillus niger & 2.23 & 3.35 & 3.00 & 2.86 \\
\hline LSD 0.05 & \multicolumn{5}{|c|}{0.32} \\
\hline
\end{tabular}


Fig 9:Effect of nano application on zones of growth inhibition

$(\mathrm{cm})$ around raw cotton ,yarn and fabric .

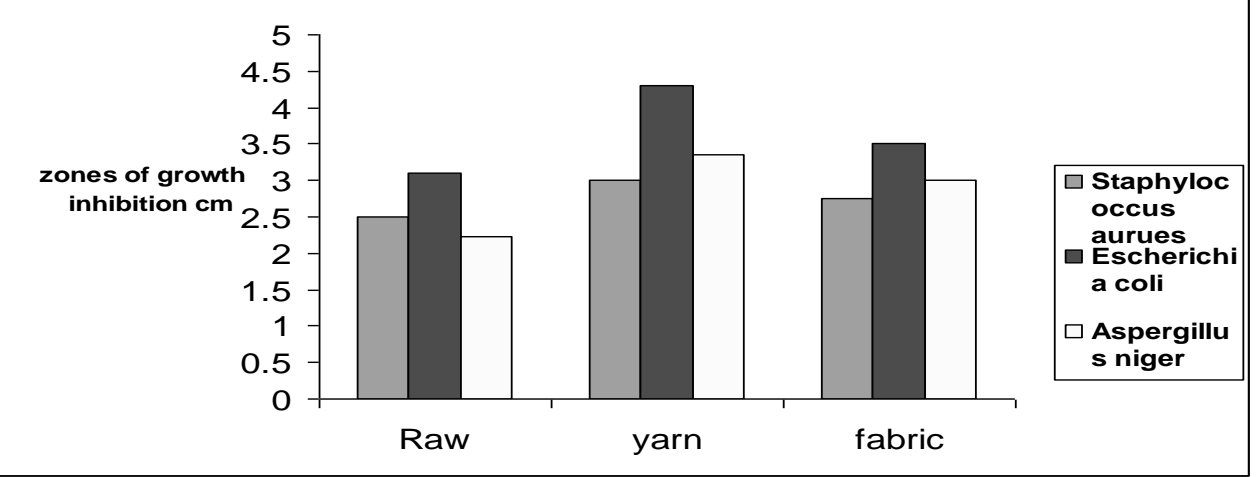

Fig 9. Effect of nano application on zones of growth inhibition $(\mathrm{cm})$ of cotton fiber, yarn and fabric

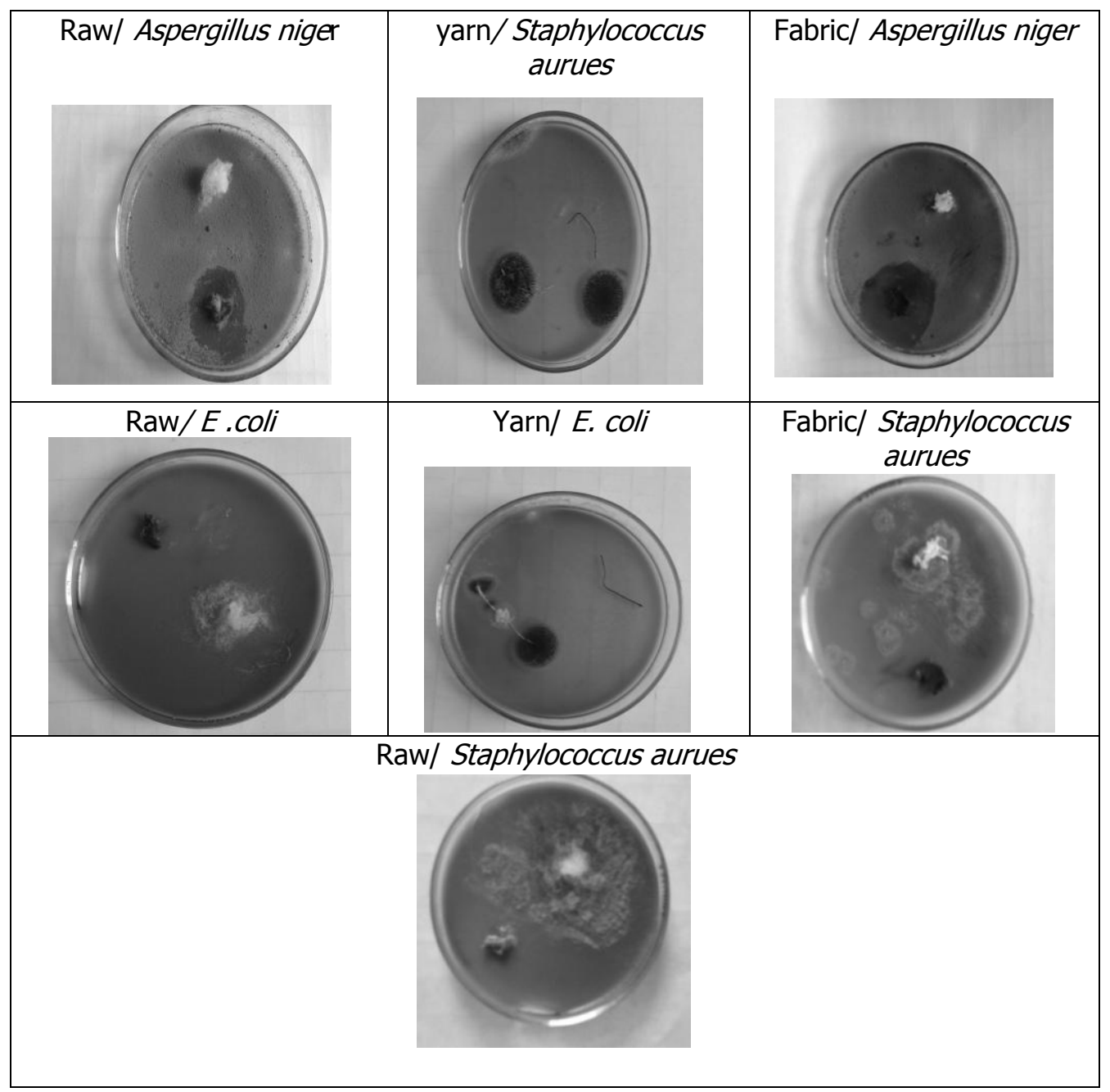

Fig. 10. Agar diffusion test showing the effect of nano application on zones of growth inhibition $(\mathrm{cm})$ of cotton fiber, yarn and fabric 


\section{REFERENCES}

1. Abdel-Salam, M.E. 1999. The Egyptian Cotton, Production, Quality and Marketing, Textile Book Elkalema Press.

2. American, Society for Testing and Materials ASTM Designation: D: 1448-2006, D: 2130-1986, : D1445-1982, : D1447-1982,and D. 2495-87.

3. Bahlool S. O., and A. S. Arafa. 2012. Measuring the Specific Surface Area of some Egyptian cotton genotypes using Methylene Blue Absorption The first cotton international conference, Saba basha faculty, Alexandria university, 17-18 April 2012, Alexandria ,Egypt.

4. Condon B., K.V. Singh, S.S. Pang , G. Li and D. Hui. 2008. A.P.S. Modern Applications of Nanotechnology in Textiles Sawhney, Textile Research Journal 78(8) 731-739.

5. Chaudhari S. B. , A. A. Mandot and B.H. Patel. 2012. Effect of nano TiO2 pretreatment on functional properties of cotton fabric. Volume 1, Issue 9, PP.24-29

6. Chun, D.T.W., and G.R. Gamble. 2007. Using the reactive dye method to covalently attach antibacterial compound to cotton. J. Cotton Sci. 11:154-158.

7. El-Nahhal, I. M S.M. Zourab, F.S .Kodeh, M. Selmane, I. Genois and F. Babonneau. 2012. synthesis, characterization, and applications of Nanostructured copper oxidecotton fibers: .International Nano Letters 2:14.

8. Gao, Y. and Cranston R. 2008. Text Res J, 7860.

9. Jiachong C. and J. Yan . 2006. " Antimicrobial yarn having nano-silver particles and methods for manufacturing the same", Publication number : WO2003080911 A3, May.

10. Ki H Y, Kim J H, Kwon S C, \& Jeong S H. 2000. J Mater Sci, 428020.

11. Lansdown, A.B. (2002) Silver. 1. Its antibacterial properties and mechanism of action. J. Wound Care 11:125-130.

12. Little, T.M. and F.J. Hills. 1978. Agricultural Experimentation Design and Analysis. John Wiley and Sons. New York.

13. Meredith, R. 1951. cotton fiber tensile strength and X-ray orientation .ext.Inst..,42:291-299.

14. Mastsumure, Y., K. Yoshikata, S.I. Kunisaki, and T. Tsuchido. 2003. " Mode of bactericidal action of silver zeolite and its comparison with that of silver nitrate" Appl. Environ. Microbial. 169:4278-4281.

15. Morones JR, Elechiguerra JL, Camacho A, Holt K, Kouri JB, Ramirez JT. 2005. The bactericidal effect of silver nanoparticles Nanotechnology. 16:2346-53.

16. Panacek A, Kvitek L, Prucek R, Kolar M, Vecerova R, Pizurova N., Silver. 2006. colloid nanoparticles: synthesis, characterization, and their antibacterial activity. Journal of Physical Chemistry: Part B,110:16248-53.

17. Qin, Y., C. Zhu, Y. Chen, and C. Zhang. 2006. "The absorption and release of silver and zinc ions by chitosan fibers.", J. Appl. Polymer Sci. 101:766-771.. 


\title{
تطبيقات النانوتكنولوجى على ألياف وغزل و نسيج القطن و تاثير ها على صفات الجودة ومقاومة الميكروبات
}

\author{
عبير سمير عرفة ، سوزان حسين سنا ، شيرين عمر بهلول
}

$$
\text { معه بحوث القطن - مركز البحوث الزراعية - الجيزة - مصر }
$$

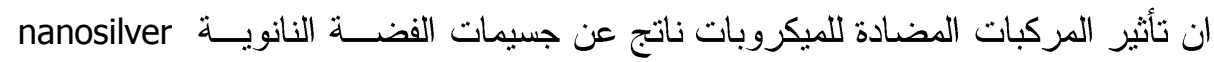

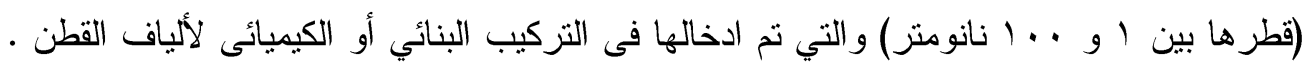

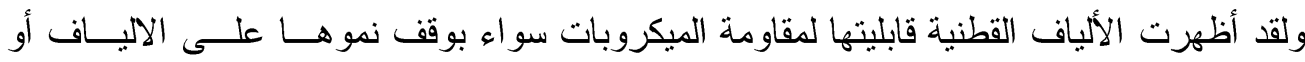

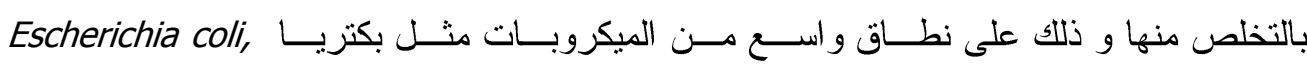
Aspergillus nigera وفطر ونط Staphylococcus aurues

وتم اجر اء هذه الدر اسة باستخدام صنف القطن جيزة 1 ، ، و دراسة تــأثير تطبيــق نـانو الفضة على خواص جودة القطن و مدى فعالية مقاومة الميكروبات من مرحلة القطن الخام (شعر)

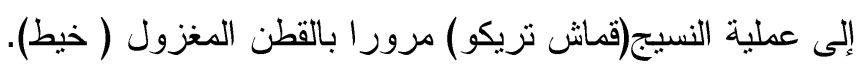

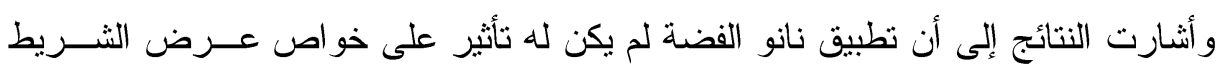
وribbon width

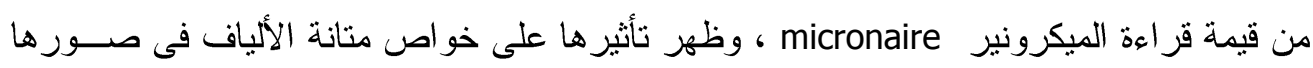

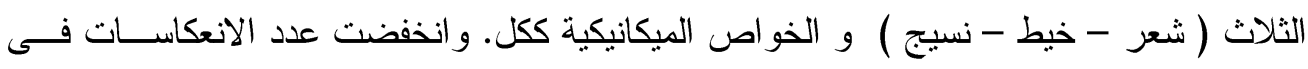

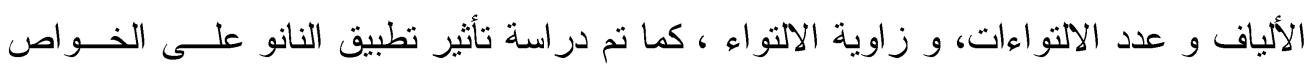

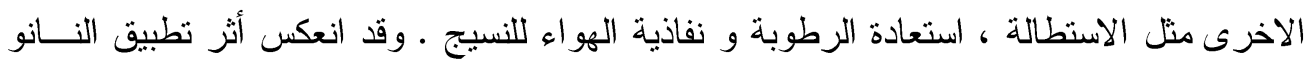

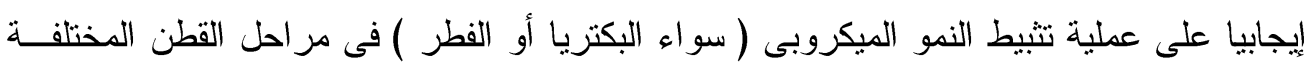

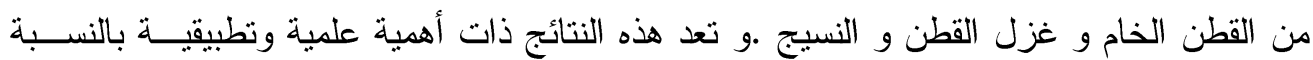
للقطن المصرى واستخداماته وخاصة فى مجال المنسوجات الطبية. 